\title{
PEMANFAATAN UAP PLTP LAHENDONG UNTUK INDUSTRI PABRIK GULA AREN
}

\author{
Jamal $^{1}$, Lydia Marghariet ${ }^{2}$, Rhesa Aristo ${ }^{2}$
}

\begin{abstract}
Abstrak: Umumnya pembangkit listrik tenaga panas bumi (PLTP) hanya memanfaatkan uap panas bumi sebagai sumber energi panas dan mengubahnya menjadi energi listrik. Pada kajian ini uap panas bumi pada PLTP Lahendong akan dimanfaatkan tidak hanya untuk menghasilkan, listrik tetapi juga untuk industri proses yakni industri gula semut aren (palm sugar)dengan sistem combine heat and power(CHP). Nira aren dipanaskan menggunakan uap panas bumi dengan alat pemanas yang disebut juicer pada proses awal atau proses pemurnian hingga $70{ }^{\circ} \mathrm{C}$. Selanjutnya proses penguapan untuk mengurangi kadar air dengan pemanasan sampai $120{ }^{\circ} \mathrm{C}$ pada evaporator. Proses ini untuk menguapkan air yang masih terkandung dalam nira pada temperatur $70{ }^{\circ} \mathrm{C}$ dengan kondisi vakum dan sambil melakukan pengadukan secara merata dan konstan. Hasil kajian ini menunjukkan bahwa gula aren yang berbentuk kristal atau berbentuk serbuk, dapat dihasilkan sebanyak 2,5 ton dari bahan baku nira sebanyak 22000 liter per hari dengan kebutuhan uap \pm 4 ton/jam.
\end{abstract}

Kata kunci : gula aren, PLTP, CHP

\section{PENDAHULUAN}

Produk akhir dari pabrik gula aren adalah gula semut (gula aren) yang diperoleh dari bahan baku nira aren. Melalui beberapa tingkat proses, dihasilkan produk gula yang diinginkan dengan bentuk, ukuran yang tertentu (pouder). Secara umum proses pembuatan gula dilakukan melalui beberapa stasiunantara lain : Proses pemurnian pada juicer, proses penguapan pada evaporator, penjenuhan dan pengadukan pada pan vacuum. Sistem yang akan dikaji dalam penelitian ini ialah aplikasi kogenerasi/CHP (Combine Heat and Power). Penerapan sistem CHP pada sistem PLTPmemiliki potensi yang besar dengan pemanfaatan energi panas dalam bentuk uap yang dapat dimanfaatan untuk proses di pabrik gula. Namun, untuk merealisasikan ide tersebut dibutuhkan kajian yang mendalam serta desain yang sesuai dengan kondisi PLTP dan pabrik gula tanpa merusak sistem pembangkitan listrik pada PLTP tersebut. Sebanyak 6.285 petani ikut menikmati berkah limbah geotermal tersebut. Energi panas bumi ini juga menyelamatkan 200.000 pohon per tahun jika dibandingkan dengan banyaknya kayu bakar untuk mengolah nira menjadi gula aren secara tradisional. Keuntungan yang bisa dinikmati petani meningkat dan kerja lebih efisien. Dengan cara tradisional membutuhkan waktu setengah hari untuk memanen nira dan mengolahnya menjadi gula, tetapi dengan dukungan limbah panas bumi hanya dibutuhkan waktu kerja rata-rata 4,2 jam per hari. Tingginya minat petani membuat Smits berancang-ancang mengganti pipa pemasok gas panas bumi menjadi berdiameter 10 inci $(25,4$ $\mathrm{cm})$ agar bisa memproduksi 9 ton gula aren per hari.

Kajian teoritis dilakukan untuk analisis kerugian energi aliran uap dari header PLTP sampai proses akhir produk gula aren. Proses akhir ialah proses pengkristalan pada pan vakum.

\subsection{PLTP Lahendong}

PLTP Lahendong terdiri atas 4 unit dan terletak di Kecamatan Tomohon Selatan, Unit 1-2 terletak di Kelurahan Tondangow dan Unit 3-4 di Kelurahan Pangolombian. Situasi power house unit 1 dan 2 ditunjukkan pada gambar 1 berikut ini.

\footnotetext{
${ }^{1}$ Staf Pengajar D4 Jurusan Teknik Mesin Politeknik Negeri Ujung Pandang

${ }^{2}$ Alumni Program D4 Jurusan Teknik Mesin Politeknik Negeri Ujung Pandang
} 


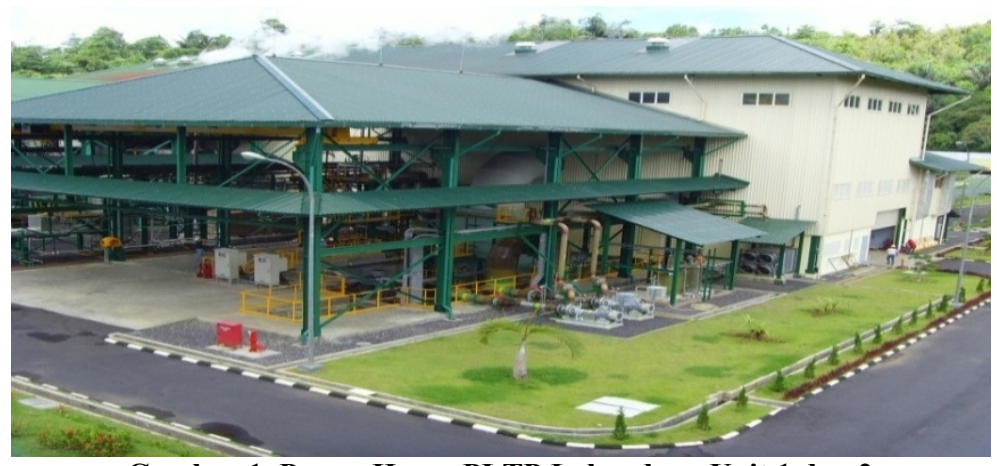

Gambar 1. Power House PLTP Lahendong Unit 1 dan 2

Suplai uap dari sumur produksi PT. Pertamina melalui suatu sistem disalurkan ke cyclon scrubber dan merupakan tempat mulai beralihnya kepemilikan Uap Panas bumi dari Pertamina ke PLN. Uap disalurkan ke demister untuk memisahkan moisture yang terkandung dalam uap, sehingga diharapkan uap bersih yang akan masuk ke dalam turbin.Konversi energi terjadi dari energi potensial uap menjadi energi kinetik yang diterima oleh sudu-sudu turbin, kemudian dikonversikan menjadi energi mekanik menggerakan generator.Exhaust steam dari turbin dikondensasikan di dalam kondensor dengan sistem direct contact condensor. Dari kondensor air hasil kondensasi dialirkan oleh main cooling water pump masuk ke cooling tower.Selanjutnya air hasil pendinginan dari cooling tower disirkulasikan kembali ke dalam kondensor sebagai media pendingin. Overflow dari basin cooling tower akan ditampung di settling basin,selanjutnya melalui sistem gravitasi maupun reinjection pump, air disalurkan ke Pertamina untuk di injeksi ke sumur injeksi. Untuk pengisian awal air ke basin cooling tower menggunakan air dari raw water.

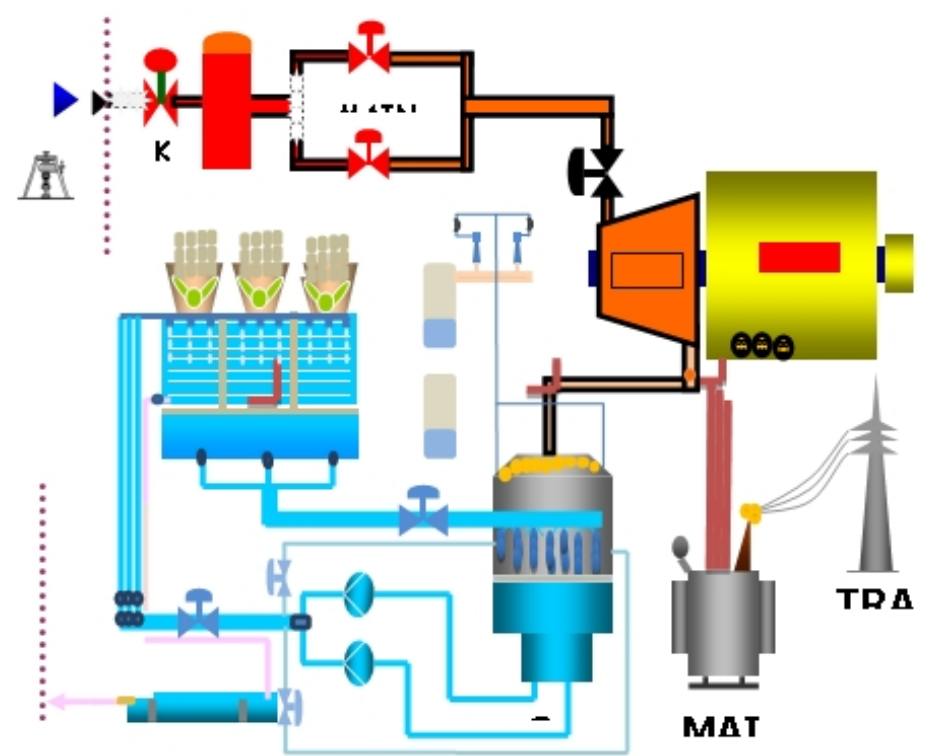

Gambar 2. Skema Pembangkitan PLTP Lahendong (dok.PLTP)

Gambar 2 menunjukkan skema sederhana pembangkit PLTP Lahendong. Adapun uap yang digunakan dapat dilihat pada tabel 1 .

Tabel 2.1 Karakteristik Uap

\begin{tabular}{|l|c|c|c|c|}
\hline Steam Characteristic & Unit 1 & Unit 2 & Unit 3 & Unit 4 \\
\hline Pressure (Bar g) & 7,8 & 7,2 & 7,13 & 7,13 \\
\hline
\end{tabular}




\begin{tabular}{|l|l|l|l|l|}
\hline Temperature $\left({ }^{\circ} \mathrm{C}\right)$ & 171 & 173 & 165,7 & 165,7 \\
\hline Flow rate (Ton/Hour) & 146 & 150 & 165 & 168 \\
\hline
\end{tabular}

(dok.PLTP Lahendong)

\subsection{Pabrik Gula Aren}

Gula aren ialah pemanis yang terbuat dari getah (sap) tanaman aren (Arenga Pinnata) sebagai penghasil getah yang discebut nira dan buah aren yang disebut kolang-kaling.
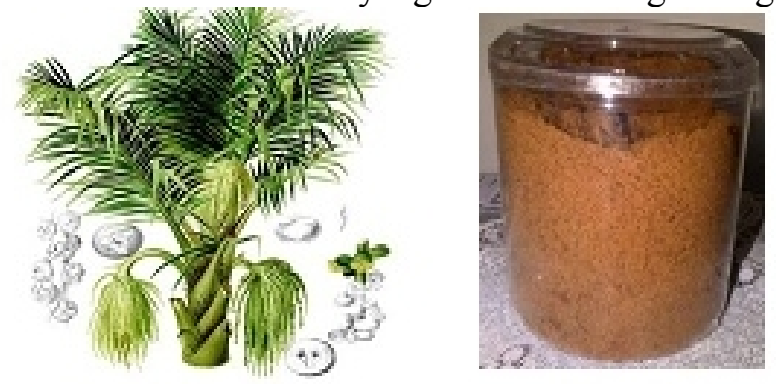

Gambar 3. Pohon Aren dan Gula Semut Aren

Proses pembuatan gula aren dari pohon aren sudah berlangsung sejak lama dan dipraktekkan oleh masyarakat di Sulawesi Utara secara turun-temurun. Peralatan yang digunakan dan cara pengolahan masih dilakukan secara sederhana. Namun saat ini, para petani gula aren mulai mengembangkan produk turunan dari gula aren menjadi gula semut (Lasut 2012).

\subsection{Proses Pembuatan Gula Aren dengan Memanfaatkan Uap Geothermal}

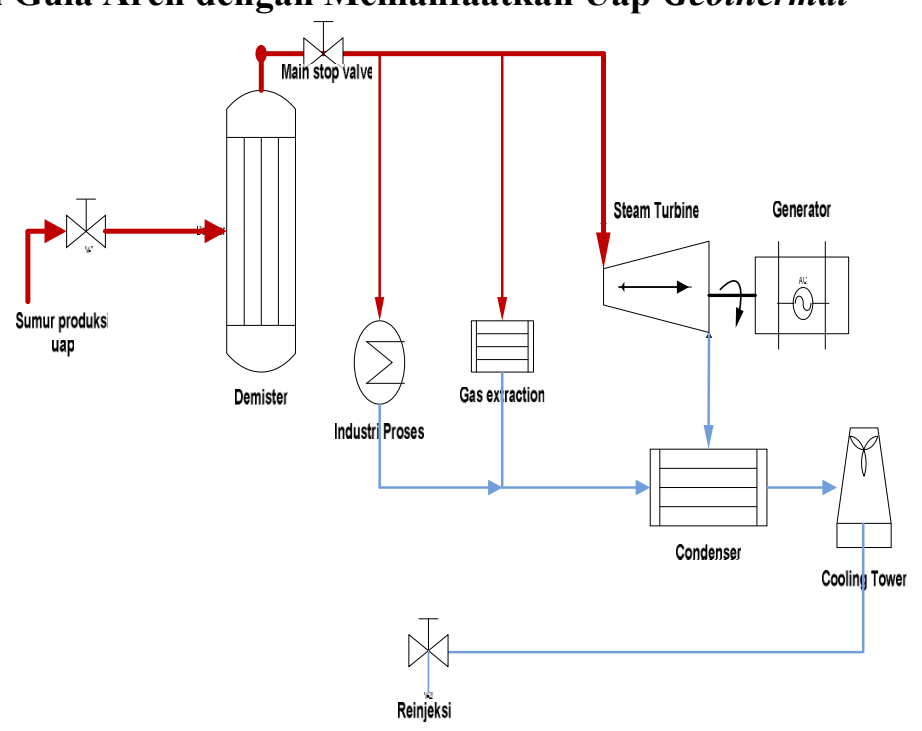

Gambar 4. Skema Combine Heat and Power pada PLTP untuk Industri Proses Gula Aren

Gambar 4 menunjukkan penerapan sistem combine heat and power atau kogenerasi pada pembangkit PLTP untuk industri proses yakni pabrik gula aren. 


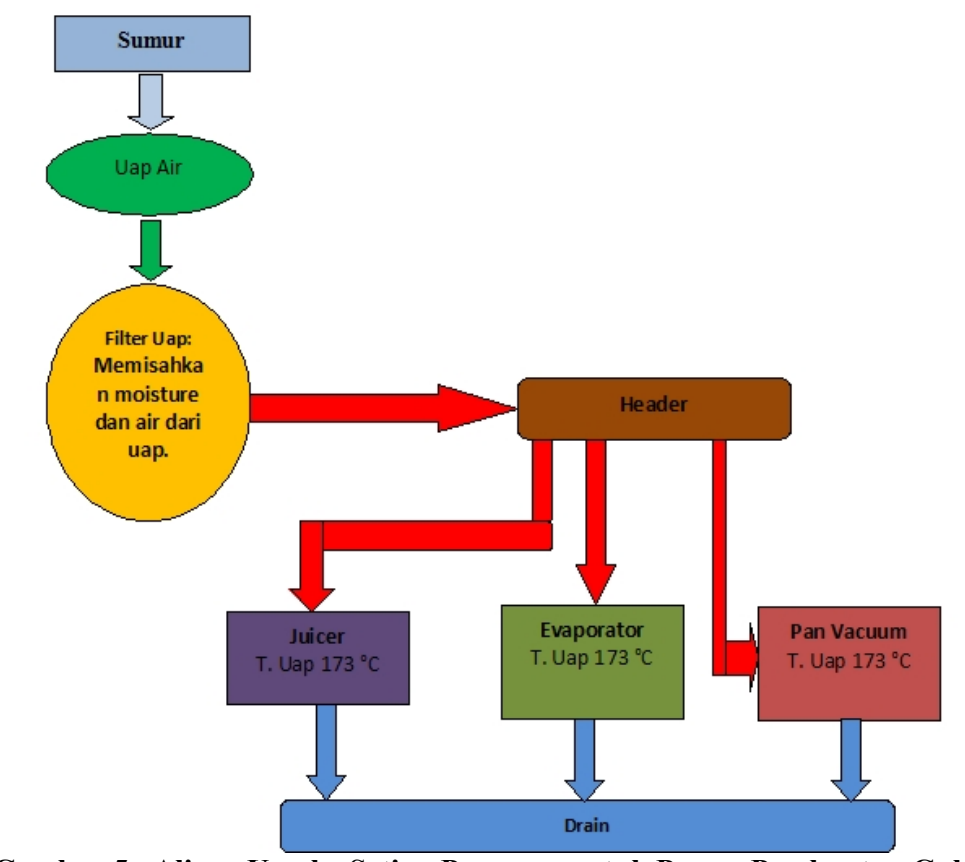

Gambar 5. Aliran Uap ke Setiap Pemanas untuk Proses Pembuatan Gula

Gambar 5 menunjukkan aliran uap panas bumi kesetiap pemanas untuk proses pembuatan gula semut pada pabrik gula aren. Proses pemanfaatan nira aren mulai dari pohon sampai pada proses pemasakan nira aren hingga menjadi gula semut dapat dilihat pada gambar 6 .

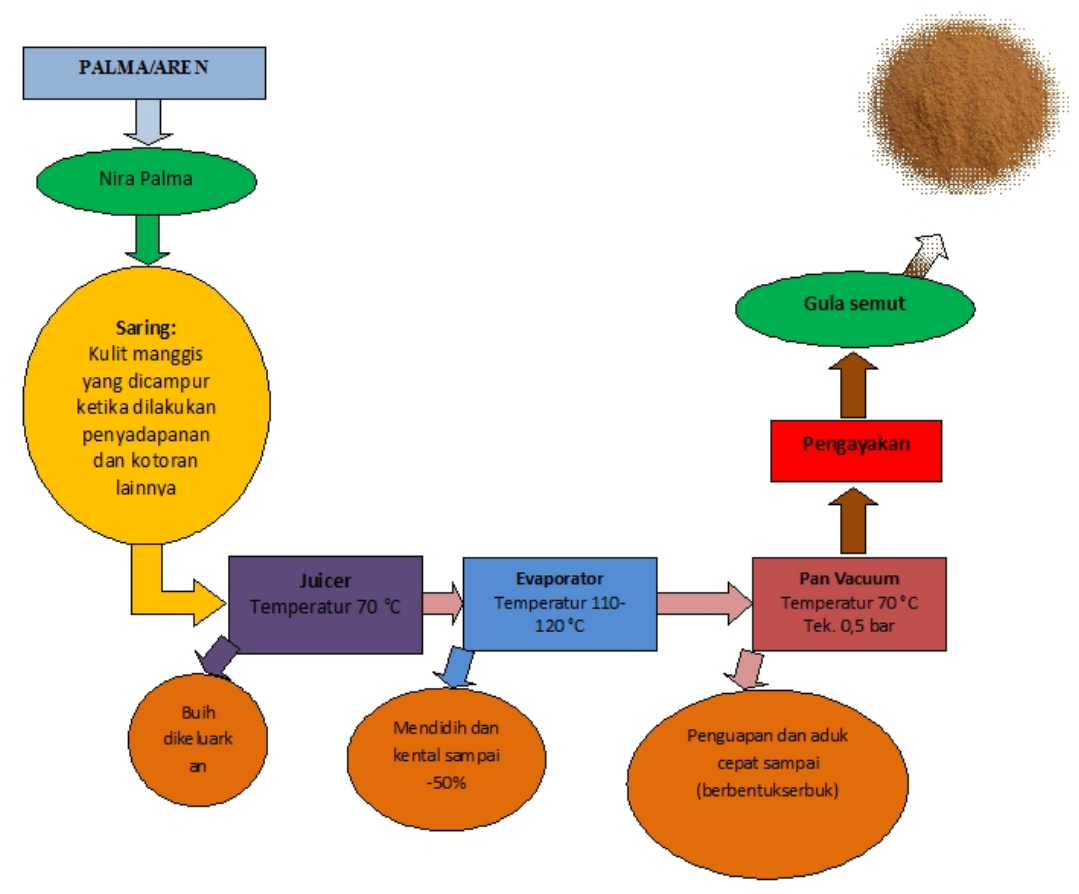

\section{METODE PENELITIAN}

Gambar 6. Skema Aliran Nira pada Proses Gula Semut

Adapun penelitian dan pengambilan data dari kajian ini di lakukan di Program Studi Teknik Pembangkit Energi Jurusan Teknik Mesin Politeknik Negeri Ujung Pandang dan data sekunder 
diperoleh dari PT. PLN (Persero) Wilayah Suluttenggo Sektor Pembangkitan Minahasa PLTP Lahendong dan Pabrik Gula Masarang Tomohon Sulawesi Utara.

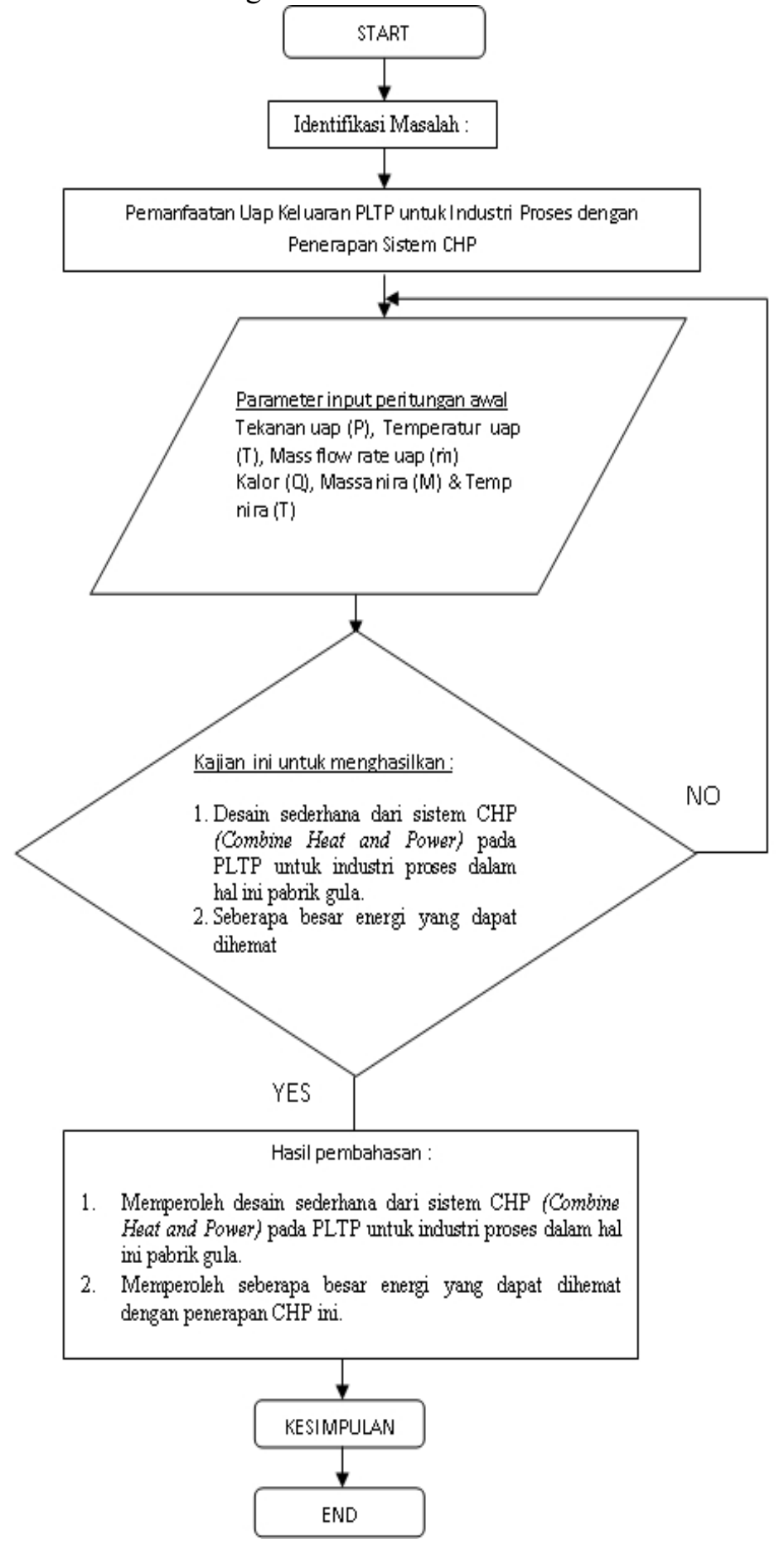

Gambar 7. Diagram Alir Proses Pemanfaatan Uap Panas Bumi dengan Penerapan Sistem combine heat and power

\section{HASIL DAN PEMBAHASAN}

(CHP)

\section{A. Hasil}

Data-data yang dibutukan untuk kebutuhan analisa desain sederhana pemanfaatan uap PLTP untuk industri proses yang berasal dari berbagai sumber dapat dilihat pada tabel 2 dan 3 . 
Tabel 2. Data-data yang telah dihimpun dari berbagai sumber

\begin{tabular}{|c|c|c|c|c|c|}
\hline \multirow{2}{*}{ No } & \multirow{2}{*}{ Data } & \multirow{2}{*}{ Satuan } & \multicolumn{3}{|c|}{ Jumlah Pemanas } \\
\cline { 4 - 6 } & & & Juicer & Evaporator & Pan Vakum \\
\hline 1 & Temperatur nira (T1) & ${ }^{\circ} \mathrm{C}$ & 29 & 70 & 120 \\
\hline 2 & Temperatur nira (T2) & ${ }^{\circ} \mathrm{C}$ & 70 & 120 & 70 \\
\hline 3 & temperatur uap (Tuap) & ${ }^{\circ} \mathrm{C}$ & 173 & 173 & 173 \\
\hline 4 & Entalphi uap (h uap) & $\mathrm{kJ} / \mathrm{kg}$ & \multicolumn{3}{|c|}{2771,6} \\
\hline 5 & ${ }^{(1)}$ Massa jenis nira (n nira) & $\left.\mathrm{kg} / \mathrm{m}^{3}\right)$ & \multicolumn{3}{|c|}{1067,5} \\
\hline 6 & ${ }^{(2)} \mathrm{Cp}$ nira & $\mathrm{kJ} / \mathrm{kg}^{\circ} \mathrm{C}$ & \multicolumn{3}{|c|}{3,467} \\
\hline 7 & ${ }^{(3)}$ Brix nira & $\%$ & \multicolumn{3}{|c|}{11} \\
\hline 8 & ${ }^{(4)}$ Pemakaian uap & Ton/jam & \multicolumn{3}{|c|}{4} \\
\hline 9 & ${ }^{(5)}$ Bahan baku nira & Liter & \multicolumn{3}{|c|}{22000} \\
\hline
\end{tabular}

Sumber: ${ }^{(1)}$ Winarno,F.G 2002, ${ }^{(2)}$ Tandiolok 2011, ${ }^{(3)}$ Pontoh,dkk 2011, ${ }^{(4,5)}$ Arif 2012

Tabel 3. Biaya Oprasional Dan Pembangunan Industri gula

\begin{tabular}{|l|l|l|}
\hline biaya tetap & $\mathrm{Rp} 8.000 .000 .000,00$ & investasi awal \\
\hline produk gula semut & 2,5 ton & per hari \\
\hline Harga Gula Semut & $\mathrm{Rp} 19.000,00$ & per kg \\
\hline Gaji Kariawan & $\mathrm{Rp} 2.400 .000,00$ & per bulan \\
\hline Jumlah Karyawan & 35 orang & \\
\hline Harga Nira Aren & $\mathrm{Rp} 1.500,00$ & per liter \\
\hline jumlah hari kerja & 312 hari per tahun & 26 hari per bulan \\
\hline Biaya maintenance & $\mathrm{Rp} 8.522 .708,00$ & per bulan \\
\hline \multirow{2}{*}{ biaya bahan bakar } & $\mathrm{Rp} .639 / \mathrm{kg}$ & kayu bakar \\
\cline { 2 - 3 } & $\mathrm{Rp} .2 .471,15 / \mathrm{kg}$ & Solar \\
\cline { 2 - 3 } & $\mathrm{Rp} .1 .374 / \mathrm{kg}$ & Uap PLTP \\
\hline
\end{tabular}

Untuk mengetahui jumlah bahan bakar yang dibutuhkan dalam industri gula aren maka dibutukan data sebagai berikut:

$\mathrm{LHV}_{\text {solar }}=43,4 \mathrm{~mJ} / \mathrm{kg}=43.400 \mathrm{~kJ} / / \mathrm{kg}$,

Berat jenis solar $=840 \mathrm{~kg} / \mathrm{m}^{3}$,

Harga solar untuk industri $=$ Rp. 7.200/liter,

Harga Kayu Bakar = Rp. 35.000-125.000/ $\mathrm{m}^{3}$.

1. Desain Sederhana Sistem Pada PLTP untuk Industri Gula Aren

Melakukan perhitungan dengan menggunakan persamaan:

$\mathrm{Q}=\mathrm{V} \times \rho \times \mathrm{Cp} \times \Delta \mathrm{T}$ atau $\mathrm{Q}=\dot{\mathrm{m}} \times \mathrm{Cp} \times \Delta \mathrm{T}$

Dimana :

Q : jumlah panas $(\mathrm{kJ})$

$\mathrm{V} \quad$ : laju alir bahan $\left(\mathrm{m}^{3} / \mathrm{jam}\right)$

$\rho \quad:$ massa jenis $\left(\mathrm{kg} / \mathrm{m}^{3}\right)$

$\dot{\mathrm{m}} \quad$ : masa bahan $(\mathrm{kg} / \mathrm{jam})$

$\mathrm{Cp} \quad$ : panas jenis bahan $\left(\mathrm{kkal} / \mathrm{kg}^{\circ} \mathrm{C}\right)$

$\Delta \mathrm{T} \quad$ : perbedaan suhu $\left({ }^{\circ} \mathrm{C}\right)$

$\mathrm{BEP}_{\mathrm{Q}} \quad=\frac{F}{(P-v)} \ldots \quad$..

Ket :

$\mathrm{BEP}_{\mathrm{Q}} \quad=$ kuantitas titik impas

$\mathrm{F} \quad=$ biaya tetap /investasi awal (Rp)

$\mathrm{P} \quad=$ harga jual per unit $(\mathrm{Rp} / \mathrm{kg})$

$\mathrm{v} \quad=$ biaya variable $(\mathrm{Rp})$

$\mathrm{BEP}_{\mathrm{Rp}} \quad=\left(\frac{F}{1-\frac{p}{v}}\right)$

$\mathrm{BEP}_{\mathrm{Rp}} \quad=$ jumlah rupiah 


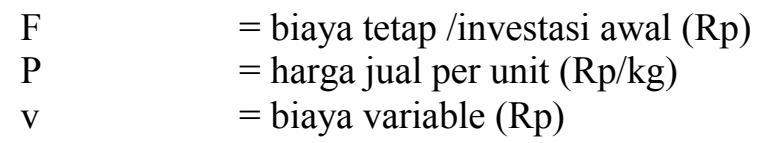

Setelah melakukan analisis dengan mengggunakan persamaan (1), (2), (3). Dihasilkan beberapa parameter dari desain sederhana dari pemanfaatan uap PLTP untuk industri gula aren dapat dilihat pada tabel 4 dan 5 .

Tabel 4. Hasil Analisa Data Desain Sederhana Industri Gula Aren

\begin{tabular}{|c|l|c|c|c|c|}
\hline \multirow{2}{*}{ No } & \multirow{2}{*}{ Parameter Hasil } & \multirow{2}{*}{ Satuan } & \multicolumn{3}{|c|}{ Jenis Pemanas } \\
\cline { 4 - 6 } & & & Juicer & Evaporator & Pan Vakum \\
\hline 1 & Efisiensi $(n)$ & $\%$ & 70,54 & 64,18 & 70,54 \\
\hline 2 & Temperatur nira $(\mathrm{T})$ & ${ }^{\circ} \mathrm{C}$ & 70 & $110-120$ & 70 \\
\hline 3 & Perbedaan temperatur $(\Delta \mathrm{T})$ & ${ }^{\circ} \mathrm{C}$ & 41 & 50 & - \\
\hline 4 & Temperatur uap $(\mathrm{T})$ & ${ }^{\circ} \mathrm{C}$ & 173 & 173 & 173 \\
\hline 5 & Volume Nira $(\mathrm{V})$ & $\mathrm{m}^{3} / \mathrm{jam}$ & 0,733 & 0,722 & 0,361 \\
\hline 6 & Massa Nira $(\mathrm{m})$ & $\mathrm{Kg}$ & 782,5 & 770,7675 & 385,3675 \\
\hline 7 & Jumlah Panas $(\mathrm{Q})$ & $\mathrm{kJ} / \mathrm{jam}$ & 236215.467 & 526054,4758 & 19758,952 \\
\hline 8 & Jumlah Panas uap $($ Quap$)$ & $\mathrm{kJ} / \mathrm{jam}$ & 334867,4043 & 815496,8392 & 28010,99 \\
\hline 9 & Massa uap $(\mathrm{m})$ & $\mathrm{kg} / \mathrm{jam}$ & 120,82 & 295,733 & 10,106 \\
\hline 10 & Diameter & $\mathrm{m}$ & 0,8 & 0,8 & 0,7 \\
\hline 11 & Tinggi & $\mathrm{m}$ & 1,46 & 1,5 & 0,95 \\
\hline 12 & Total Pemanas & Buah & 10 & 10 & 10 \\
\hline 13 & Total produksi gula semut & Ton & \multicolumn{3}{|c|}{} \\
\hline
\end{tabular}

Tabel 5. Hasil Analisa BEP Dengan Membandingkan Tiga Sumber Panas

\begin{tabular}{|c|c|c|c|}
\hline & Uap & Kayu bakar & Solar \\
\hline Total biaya Variabel & Rp. 16.486,13 & Rp. 15.751,13 & Rp. 18.222,28 \\
\hline Bep jumlah produksi & 3182,344 ton & 2462,39462 ton & 10286,4784 ton \\
\hline Bep jumlah penghasilan & Rp. 60.464.546.084 & Rp. 46.785.497.730 & Rp. 195.443.090.010 \\
\hline Bep priode operasi & 10,2 Tahun & 7,9 Tahun & 33 Tahun \\
\hline
\end{tabular}

\section{B. Pembahasan}

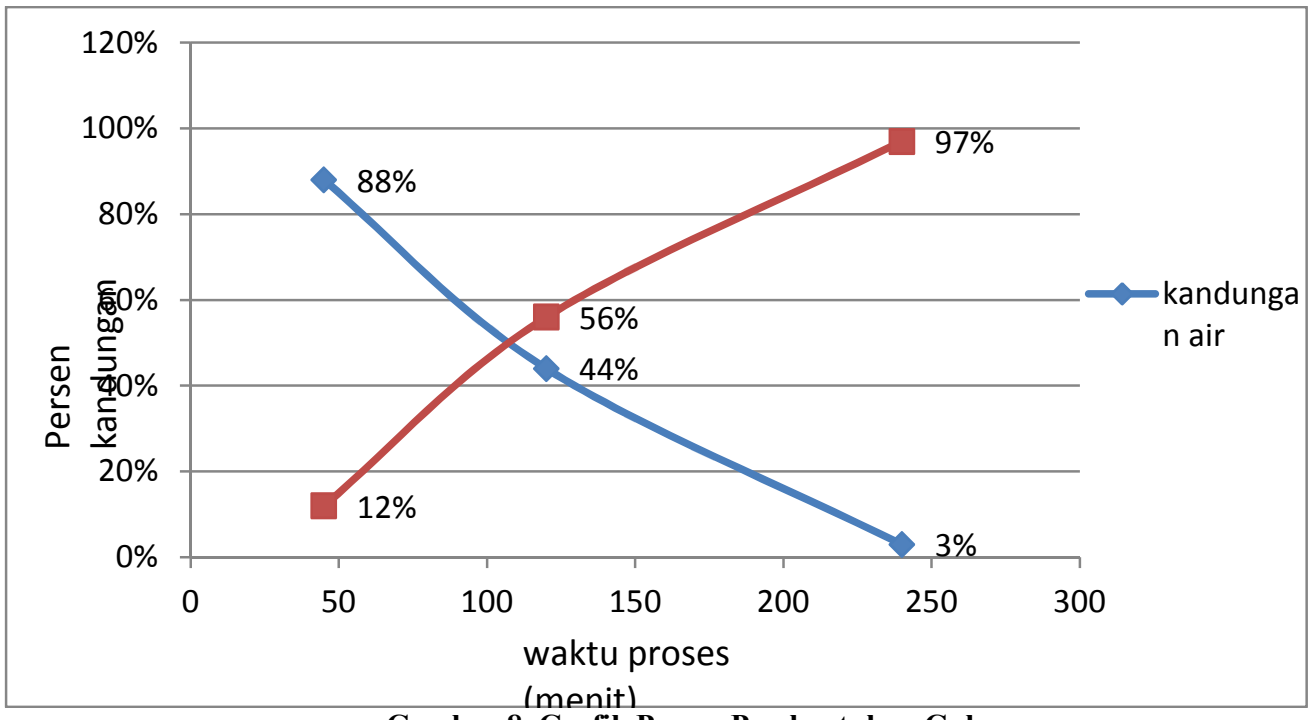

Gambar 8. Grafik Proses Pembentukan Gula

Dapat dilihat pada gambar 8 hubungan waktu dengan tahapan proses pembentukan gula pada nira tesebut. Grafik ini menunjukkan bahwa semakin bertambahnya waktu proses pemasakan maka kandungan air pada nira tersebut semakin berkurang akibat terjadinya penguapan, dengan waktu 
proses selama \pm 4 jam terjadi berbagai perlakuan pada nira yang bertujuan untuka menguapkan air semaksimal mungkin dan menghasilkan gula semut yang berkualitas dan berdaya jual tinggi, ketika kandungan air pada nira telah diuapkan maka kandungan yang masih tertinggal dari nira tersebut adalah gula (gula semut aren).

Gambar 9 adalah gambar desain sedehana dari pabrik gula aren yang dilengkapi dengan gambar masing-masing bagian komponen yang digunakan untuk mengolah nira menjadi gula semut.

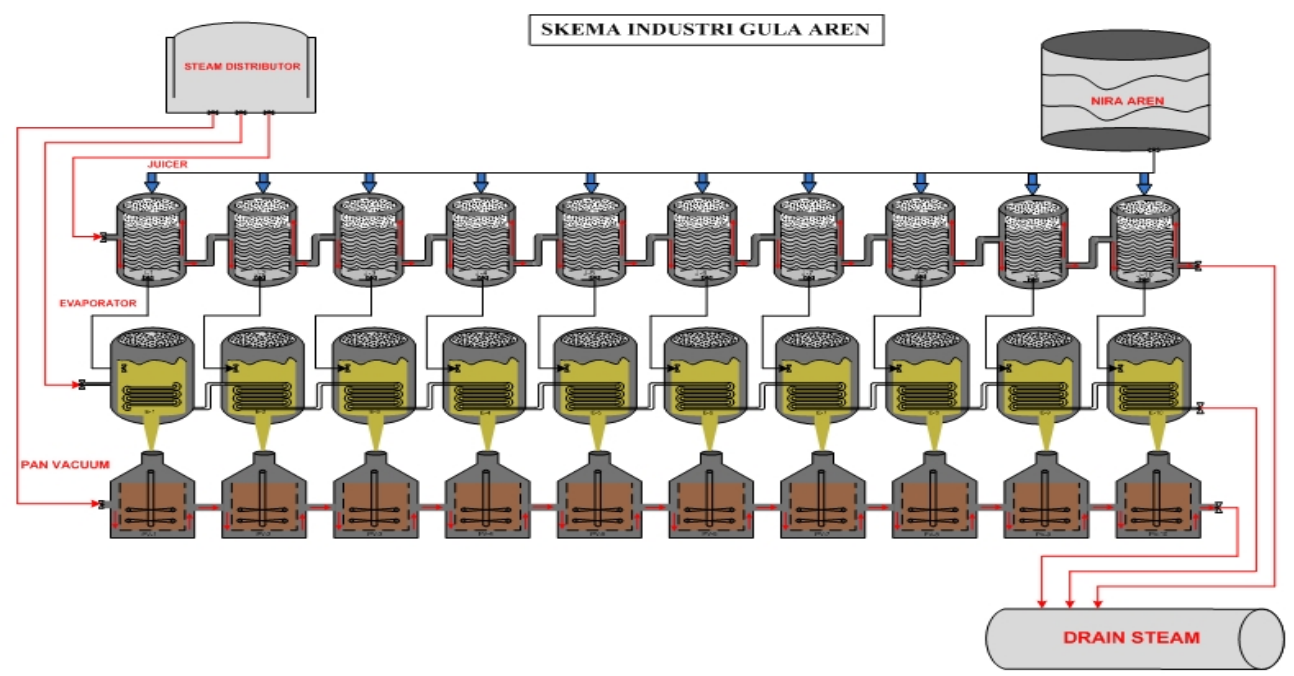

Gambar 9. Skema Pabrik Gula Nira

Gambar 10 menunjukkan waktu proses pemasakan nira selama satu hari sehingga menghasilkan produk gula aren $\pm 2,5$ ton, dengan jumlah bahan baku nira 22000 liter dengan waktu proses 8 jam/hari.

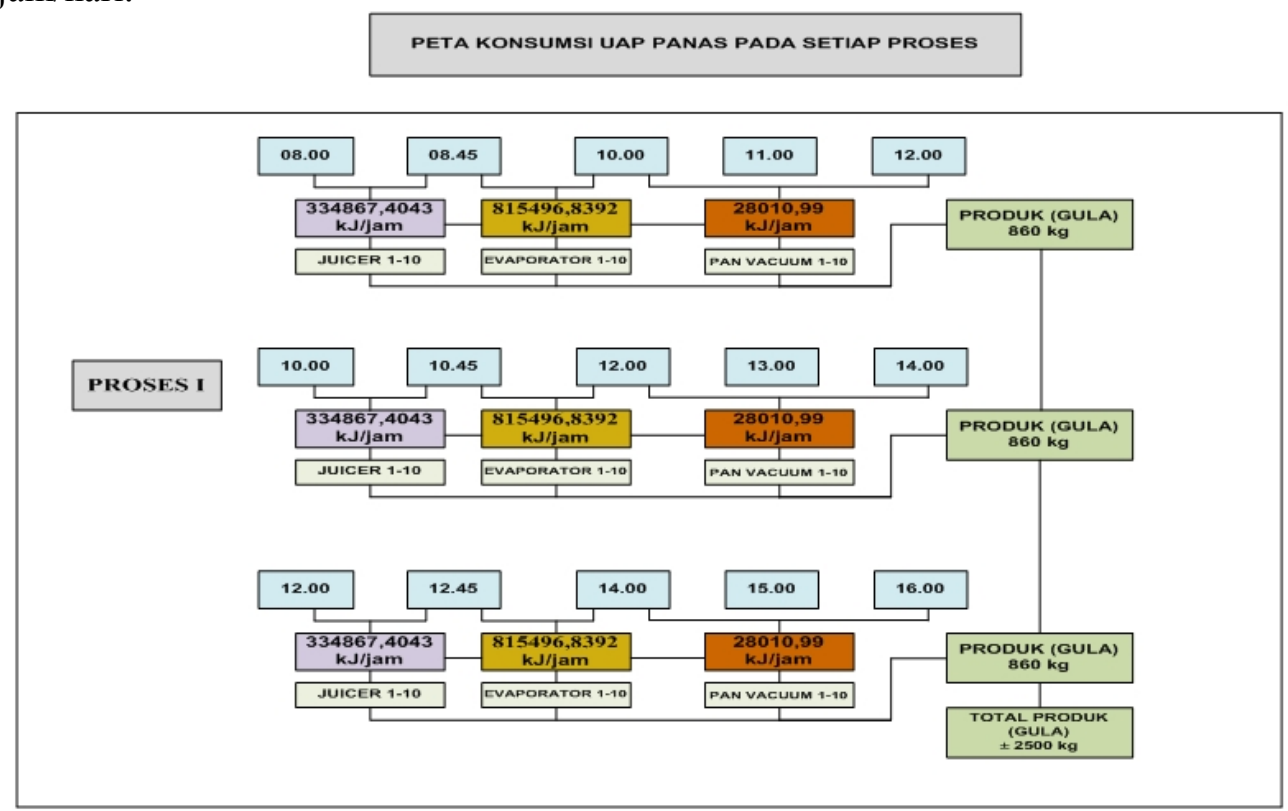

Gambar 10. Formasi Pemasakan Nira Menjadi Gula Aren 


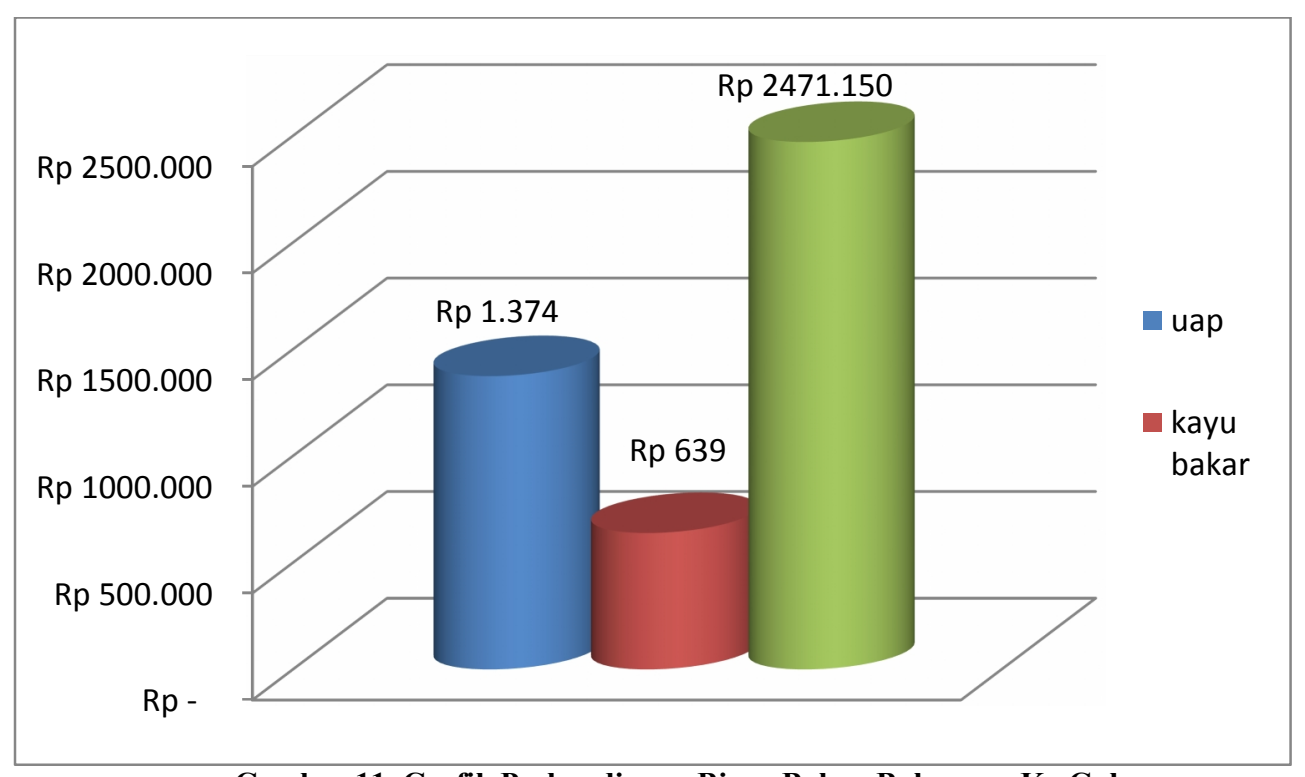

Gambar 11. Grafik Perbandingan Biaya Bahan Bakar per Kg Gula

Dari gambar 11 dapat dilihat bahwa jika menggunakan uap sebagai sumber panas pemasakan gula semut biayanya Rp.1.374/kg gula, jika menggunakan kayu bakar Rp.639/kg gula dan jika menggunakan solar Rp. $2.471,15 / \mathrm{kg}$. Biaya penggunaan solar dianggap terlalu besar untuk proses pembuatan gula semut dalam skala besar. Dalam penelitian ini kapasitas masakan nira aren untuk dijadikan gula semut adalah sebanyak $2500 \mathrm{~kg}$ (2,5 ton).

\section{KESIMPULAN DAN SARAN}

\section{A. Kesimpulan}

1. Desain sederhana ini secara garis besar ada tiga proses yaitu pemanasan/pemurnian dengan menggunakan alat juicer, penguapan dengan mengunakan alat evaporator, dan pemasakan atau kristalisasi dengan menggunkan alat pan vakum. Untuk memproduksi gula dibutuhakan waktu selama 4 jam untuk proses keseluruhan di butuhkan waktu \pm 8 jam perhari untuk memasak 22000 liter dan menghasilkan gula aren semut sebanya 2,5 ton dengan mempekerjakan 35 orang kariayawan. Kualitas gula semut yang baik berwarna kuning kecoklatan dan dengan kadar air tidak lebih dari $3 \%$.

2. Penghematan energi tidak hanya ditinjau dari penghematan biaya produksi tetapi dari sisi kontinuitas sistem tersebut dalam jangka panjang dan peran sistem tersebut menjaga lingkungan, jadi jika memungkinkan suatu industri gula tersebut menggunakan uap panas bumi akan lebih baik daripada menggunakan kayu bakar dengan solar.

B. Saran

Dari penelitian ini maka disarankan: untuk melakukan analisis lebih terpusat pada masing-masing tahapan proses dari pabrik gula tersebut seperti isolasi uap pada pipa distribusi uap, juicer, evaporator dan pan vakum

\section{DAFTAR PUSTAKA}

Anonim.2014. "Proses Pembuatan Gula Aren Dengan Penggunaan Langsung Geothermal". Scribd.[online].(https://www.scribd.com/doc/239400316/Proses-

Pembuatan-Gula-Aren-Dengan-Penggunaan-Langsung-Geothermal, diakses tanggal 25 februari 2016) 
Arif. 2012. "Memanen Gula Aren dari Panas Bumi". Kompas.com. [online] (http://regional.kompas.com/read/2012/08/29/11065345/Memanen.Gula.Aren.dari.Pana s.Bumi, Diakses tanggal 2 mei 2016)

Aristo. 2015. "Sistem Air Pendingin Unit 1 PLTP Lahendong”. Laporan Kerja Praktek.Makassar : Jurusan Teknik Mesin Politeknik Negeri Ujung Pandang.

Dwiriskityani. 2016. "Efisiensi Evaporator". [online]. http://dokumen.tips/documents/efisiensievaporator.html\#, diakses tanggal 22 juli 2016.

Holman, J.P. 1995. "Perpindahan Kalor”.Jakarta : Penerbit Erlangga.

Kolamala, Suresh.2007. Co-Generation, Combined Heat And Power (CHP).

Lasut, Marthen Theogives. 2012. "Pengolahan Gula Aren". Modul. Manado. Fakultas Pertanian Universitas Sam Ratulangi.

Tandiolok. 2011. "Steam Ekonomi pada Evaporator ". Laporan Tugas Akhir. Makassar.Jurusan Teknik Kimia Politeknik Universitas Ujung Pandang.

Winarno, F.G. 2002.“Kimia Pangan dan Gizi”. P.T. Gramedia Pustaka Utama. Jakarta 